\title{
GCU
}

Glasgow Caledonian

University

University for the Common Good

\section{Gender differences in the choreography of alcohol-related violence: an observational study of aggression within licensed premises}

Forsyth, Alasdair; Lennox, J. C.

Published in:

Journal of Substance Use

DOI:

$10.3109 / 14659890902966497$

Publication date:

2010

Document Version

Author accepted manuscript

Link to publication in ResearchOnline

Citation for published version (Harvard):

Forsyth, A \& Lennox, JC 2010, 'Gender differences in the choreography of alcohol-related violence: an

observational study of aggression within licensed premises', Journal of Substance Use, vol. 15, no. 2, pp. 75-88. https://doi.org/10.3109/14659890902966497

\section{General rights}

Copyright and moral rights for the publications made accessible in the public portal are retained by the authors and/or other copyright owners and it is a condition of accessing publications that users recognise and abide by the legal requirements associated with these rights.

Take down policy

If you believe that this document breaches copyright please view our takedown policy at https://edshare.gcu.ac.uk/id/eprint/5179 for details of how to contact us. 
Gender Differences in the Choreography of Alcohol-related Violence: An observational study of aggression within licensed premises

Abbreviated title: Gender differences in alcohol-related violence

Dr Alasdair J M Forsyth PhD,

Senior Research Fellow

Scottish Centre for Crime and Justice Research

Glasgow Centre for the Study of Violence

Glasgow Caledonian University

Cowcaddens Road,

Glasgow G4 0BA

Jemma C Lennox, MSc,

Division of Psychology

George Moore Building

Glasgow Caledonian University

Cowcaddens Road,

Glasgow G4 0BA

Correspondence: Dr Alasdair J M Forsyth, Room M436, Glasgow Caledonian University, Cowcaddens Road, Glasgow G4 0BA, UK Tel. 0141-331-8301. Fax: 0141331-3636. E-mail: Alasdair.forsyth@gcal.ac.uk. 
Gender Differences in the Choreography of Alcohol-related Violence: An observational study of aggression within licensed premises

\begin{abstract}
Aims: To examine patterns of gender involvement in violent incidents observed within licensed premises. Methods: Field observations were conducted in a sample of eight city centre nightclubs allowing alcohol-related aggressive incidents to be witnessed in their naturalistic setting. Results: Although most of those involved in aggressive incidents were males (108/171), many of the conflicts witnessed involved female combatants (36.8\%). Additionally, female-to-female incidents were found to be as potentially injurious as those between males. Nevertheless, female-to-female and male-to-male conflicts did differ, in terms of the nature of the violence observed with, for example, female conflicts being less likely to involve an easily recognisable set pre-fight choreography. Conclusions: This research the challenges belief that female conflicts within licensed premises are less problematic than those involving males. These findings are discussed in terms of alcohol, masculinity and harm reduction.
\end{abstract}

Keywords: alcohol, gender, violence

Words count (excluding references and tables): 4,891 


\section{Gender Differences in the Choreography of Alcohol-related Violence: An}

observational study of aggression within licensed premises

\section{Introduction}

Alcohol consumption in barrooms, risk-taking and aggression are often seen as being among the defining characteristics of 'masculinity' in Western cultures (e.g. http://en.wikipedia.org/wiki/Masculinity; Campbell et al, 1999; De Visser \& Smith, 2007); Moynihan, 1998; Strate, 1992). This view has been backed-up by research conducted into barroom violence which has invariably found that alcohol-related aggressive incidents between females are comparatively rare compared to those involving males, with authors tending to explain this gender difference in terms of 'macho' concerns (e.g. Benson \& Archer, 2002; Graham \& Wells, 2001; Homel \& Clark, 1994; Leonard et al., 2003). This has led to the bulk of research designed to explain or reduce barroom violence traditionally having a distinctly male focus (e.g. Burns, 1980; Graham \& Wells, 2003; Murdoch \& Pihl, 1988; Lang, 1975; Tomsen, 1997).

Against this, other authors have noted that there has been a "paucity of research into women's aggression bars" (Collins et al. 2007) especially "research focusing solely on women" (Buddie \& Parkes, 2003). The exception to this rule would appear to be a body of research which identifies females who drink alcohol in bars as being at an elevated level of risk of victimisation from male aggression (e.g. De Crespigny, 2001; Parkes, 1999 \& 2000; Testa \& Parks, 1996).

When previous research into barroom violence has identified female aggressors, this has been found to be more likely to involve a male opponent (i.e. inter-gender conflict), as opposed to male conflicts which are more likely to be between males (i.e. intra-gender) (Graham \& Wells, 2001). Additionally, previous research has found that female aggressors in barroom incidents tend to use less serious types of violence, such as pushing rather than punching (Graham \& Homel, 2008). A recent Canadian study involving 1,334 observations conducted in 118 Toronto bars / nightclubs by Graham et al (2006) concluded that: "Women used different forms of aggression, inflicted less harm, and were more likely to have defensive intent compared with men" and that "women are more likely to use indirect or passive forms of aggression (e.g. angry looks / body 
language)". Previous research has also found that female barroom patrons are less likely to engage in 'macho' type behaviours, which can lead to conflict, such as threats and challenges or intimidating glaring (Graham \& Homel, 2008).

Various researchers have proposed that drinking alcohol and fighting can be an essential part of a good night out for many (young adult) males, something which has served to produce a 'macho' barroom culture characterised by a carnival atmosphere of honour, chivalry, loyalty and other 'masculine' concerns (e.g. Burns, 1980; Moore, 1990; Graham \& Wells, 2003; Hobbs et al, 2003; Tomsen, 1997). Benson \& Archer (2002, pp. 11-12) and Tuck (1989, pp. 45-46) both describe a set prequel to alcohol-related fighting between young males, a 'code' involving verbal insults, challenges, then intentional bumping or drink spilling. Graham \& Homel (2008, p71) argue that "Young men and the macho culture [is] the single most common source of conflict in many drinking contexts".

In the UK in recent times there has been a reported rise in the number of female drinkers participating in the night-time economy, who in adopting (the above) 'hyper-masculine' characteristics have been dubbed 'ladettes' by the media, (e.g. Borland, 2008; Hinsliff, 2004; McRobbie, 2004; Smith \& Taher, 2008). This has been coupled with the 'feminisation' of the barroom environment, creating a less male-orientated gentrified ontrade, resulting in the demise of the traditional pub in British city centres (BBC2 Television, 2004; Chatterton \& Hollands, 2003; Dow \& McIntosh, 2004; Hadfield, 2006). This has in turn been linked to increasing alcohol problems amongst (young adult) females (BBC3 Television, 2006; Dooldeniya et al, 2007; Gray, 2006; Harrell \& Howie, 2006; Plant et al, 2005; Slack, 2008; Taylor-Whiffen, 2006). Chatterton \& Hollands (2001) describe the transformation of a UK city's nightlife as being in part characterised by the 'feminisation' of licensed premises, but set alongside continued 'hypermasculinity', defined as heavy drinking with occasional bouts of aggression, and an atmosphere of "machismo" (p.7). Such an apparent gender paradox would seem to set the scene for an arena where alcohol-related violence involving both male and female participants may occur.

Some evidence that this is indeed the case was highlighted by previous observational research conducted in city centre licensed premises in Glasgow, Scotland (Forsyth et al, 2005), which used an identical methodology to the present paper. In that previous 'pub 
study', seven out of the eight observed pubs had a majority of male patrons, however premises (or parts of premises) which were predominantly male tended to be less disorderly. Although the number of aggressive incidents witnessed in this previous 'pub study' was small $(n=14)$, these involved an equal number of female and male patrons (32/64 combatants), yet only one staff member who intervened was female (a bar server). In the extreme, one incident involved eight women, where the initial aggressor was described as a grey-haired 50-60 year-old, aided and abetted by her pregnant daughter (two of the 14 incidents involved apparently heavily pregnant, drunk, aggressors).

\section{Method}

The research conducted for this paper involved observations being conducted within nightclubs in a Scottish city centre. Observations were carried out between February and May 2006. These involved two teams, each comprising two fieldworkers (one female and one male in each) who visited a sample of eight of Glasgow's 70 nightclubs for three hours, twice each, once on a Friday and once on a Saturday night (midnight to 3.00AM which approximates to 100 hours observation taking into account 'drinking-up time').

The eight nightclubs observed were selected in consultation with the local police (Strathclyde Police) to represent the full range of crimes of disorder they recorded at such premises. The selected premises all charged admission and offered mainstream 'high street', regular dance promotions (i.e. the sample excluded niche venues such as Gay clubs, strip clubs, comedy clubs or ceilidhs). Each of the observed premises is assigned a suitable pseudonym for the purposes of this paper.

Observers made detailed field-notes about what they had witnessed on each occasion that they visited a nightclub. They also completed two research instruments (questionnaires or checklists) on returning home after each observational session. These instruments have been extensively validated in work of this nature in Canada and elsewhere (see Graham, $1999 \& 2000)$. The first of these, 'Form1', was used to detail the nightclub (barroom) setting, for example by asking observers to estimate the proportion of patrons who were female in each venue every time they visited. The other, 'Form2', was used to record any incidents of violence witnessed, and this paper will focus on findings from this second form by providing observers' descriptions of aggressive incidents, including 
field-notes and quantitative data derived from checklists assessing what types of violence were used and their consequences.

When completing these forms observers were instructed to only record what they actually observed. Therefore when for example a fight was witnessed involving two patrons, but the observer concerned only saw one of the combatants clearly enough to describe whether or not they were injured, data for the other combatant were recorded as 'don't know'. Also, it should also be noted that the analyses below refer to observers' ratings of patrons and not actual patrons. On some occasions only one observer in a team witnessed an aggressive incident and completed a 'Form2', on other occasions both team members may have witnessed the incident, though they may, or may not, have recorded the same patrons as taking part in this conflict.

\section{Results}

\section{Conflict frequency and severity}

During observations 34 aggressive incidents were witnessed. How these incidents broke down in gender terms between the eight nightclubs and the estimated percentage of female patrons who attended each is shown in Table 1, along with the police crime data used in the selection process.

\section{$<$ Table 1>}

From Table 1, it can be seen that seven of the eight nightclubs had a majority female clientele. However, the only nightclub with a male majority was found to be the least disorderly, with no observed incidents and by far the lowest crime rate. In one of the six nightclubs where aggressive incidents were witnessed, 'Xanadu' (which had the highest police crime rate), the majority of combatants in observed incidents was female. At the other extreme, in the club where the most incidents were witnessed, 'Armageddon', only four of the 41 combatants who observers could describe were female. This latter club differed from the others in the sample in that a lax door policy had led to a scenario where there were more under-age patrons $(46.9 \%$, mean of others $10.4 \%)$, mainly under18 females, who shared this venue with many over-age, but hostile, male 'neds' (a violent Scottish subculture, http://en.wikipedia.org/wiki/Ned_\%28Scottish\%29), the common factor here being that neither group would have been likely to gain entry 
elsewhere. It is interesting to consider that if this club were excluded the proportion of males and females involved in violent disorder would have been similar.

The 34 aggressive incidents witnessed involved a total of 171 patrons, 63 (36.8\%) of whom were female. In contrast only $11(8.3 \%)$ of the 133 security staff (known in Scotland as stewards) who intervened in these conflicts were female. Only $19.7 \%$ of all stewards observed in this research were female. Female stewards were also estimated to be younger than their male colleagues (mean ages, 24.0 and 27.8 respectively, $t=3.80, p$ $=0.002)$.

Although nine of the aggressive incidents involved both male and female patrons (20 were male only and 5 female only), it is important to stress that in just one instance was the initial conflict inter-gender (i.e. female-to-male aggression), in which a male patron accidentally bumped a female who responded by "repeatedly shoving him in the chest with her open palm" (Female Observer, Incident \#33). A male steward watching nearby did not intervene, though the victim did not retaliate and he was able to walk away unhurt. When observers were asked to rate whether anyone had been injured during each conflict, there was no significant gender difference with $14(13.0 \%)$ males and $7(11.1 \%)$ females being recorded as having been "hurt" (21.2\% and $18.4 \%$ of the 66 and 38, males and females respectively for whom such an assessment could be made).

\section{Conflict tactics}

From the observers' descriptions of the aggressive incidents they witnessed it was clear that, despite little difference in their severity, conflicts involving male-to-male and female-to-female violence differed in their nature. Below are two incidents which are illustrative of the male-to-male aggression witnessed. (These use the notation ' $\mathrm{P}$ ' for any patrons and ' $S$ ' for any staff involved, along with individual identifying information).

"P1 [18-23 year-old male] was talking to P3 [17-22 year-old male] and started to 'square up' to him. P1 started to push P3 in the chest. He did this a few times and then P3 pushed him back. P1 pushed him again and P2 [18-22 year-old male] intervened, but at the same time P1 went to head-butt P3 but just clipped him. P2 then threw a punch and hit the side of Pl's head. P4 [17-24 year-old male] then joined in and shoved P2 out of the way... The whole incident was over very quickly and the bouncers arrived at the scene almost immediately." (Female Observer, Incident \#24, 'Armageddon') 
"We saw P2 [25-30 year-old Hispanic male] and P1 [21-23 year-old male] 'squaring up' then they started to grapple with each other. P3 [22-25 year-old male] then tried to pull P1 away while shouting at P2. P4 [25-31 year-old Hispanic male] was also trying to pull P2 away and as he did P2 threw a punch at P1 that hit him on the side of the head. This only took a few seconds to kick off and the bouncers, S1 and S2 [male stewards] were over straight away." (Male Observer, Incident \#12, 'Chocolate')

The similarities between the above incidents (and other male-to-male conflicts witnessed) were quite striking, considering they took place in different clubs, with different age groups, and that Incident \#12 involved two ("Hispanic") males who (given local demographics - the census does not even use this category) are likely to have been strangers to the city but who also followed the same universal male fight 'code'. Female conflicts were rather different as is illustrated by the following accounts.

"Then P1 [30-40 year-old female] and P2 [25-40 year-old female] had each other by the hair and were trying to force each others heads down. The other three women were hard to see but it looked like they initially were trying to break it up but then ended up getting involved themselves, resulting in a circle of five women all pulling each others hair. P3 [27-40 year-old female] ended up getting punched in the face by one of the other women but I am unsure who did it. Her nose was burst open and she put her hands over face. At this point P6 [24-42 year-old male] started chasing P7 [24-36 year old male] and punched him in the head and kicked him on the back of his leg... While the incident was going on about five male patrons from the club stood and filmed it on their mobiles. The steward at the door of the club would have seen what was going on but did not intervene." (Female Observer, Incident \#23, 'Sinatra's')

"It was a bit like [a previous] fight where it starts off with two. Then others (P2 [20 year-old female in blue dress] and P3 [20 year-old female with ponytail]) join in, possibly in an attempt to break it up but it just snowballs into a bigger fight... It was hard to see what was going on, it was just a mass of fighters and stewards. S5 [male steward] definitely got punched in the face by one girl possibly an accident as punches were flailing everywhere. P4 [20-21 year-old female] was extremely vicious, as during the fight she managed to take off her left shoe (possibly a stiletto) and use it to batter whoever was the initial target. ...during the fight S5 was trying to remove someone's vice-like grip from P2's hair, after getting nowhere trying to pull her arm away he bit her about two or three times on her arm and hand." (Male Observer, Incident \#26, 'Idols' - emphasis his)

Again these incidents show similarities (as did other female-to-female conflicts). Incident \#23 is of interest as the two males in this mixed gender conflict appeared to stick to the male-to-male 'stand-up' fight 'code', rather than becoming embroiled in the female melee. No staff intervened. Staff did intervene in Incident \#26, though their response seemed at best unconventional. This was to become a theme with female-to- 
female violence, a lack of appropriate interventions by, the mainly male, security staff, as the following accounts illustrate.

"P1 [19-21 year old female] and P2 [20-21 year old female] were standing with about six people round them including two males who were strangers to them who were laughing. It looked like S1 and S2 [male stewards] had just separated $P 1$ and $P 2$ from each other. P1 was holding clumps of her blonde hair extensions in her hands and looked upset and close to tears... P2 looked completely unphased. S1 was trying to talk to P1 but she wasn't really listening and S1 looked like he could hardly suppress a smirk... While S2 was holding [P2] he was looking out on to the dancefloor and dancing along to the music stamping his foot and nodding his head to the beat." (Female Observer, Incident \#17, 'Xanadu')

"P1 [18 year-old female] was actually punching $P 2$ [17-18 year-old female] in the head repeatedly. I think she might have been holding P2 by the hair but I'm not sure... Then P3 [17-18 year-old male] and P4 [18 year-old male] appeared. I don't know if they knew P1 and P2 or were trying to stop them fighting or had just been in the wrong place but when $S 1$ [male steward] turned up he grabbed them instead of the girls. Upon this I saw P1 sneak off up the back of the club." (Female Observer, Incident \#29 'Xanadu')

As well as an apparent tendency for male staff to have difficulty in dealing with femaleto-female violence (there were no such problems observed when intervening in male-tomale conflicts), the lack of female stewards seem to exacerbate the situation. Female toilets appeared to be a security blind-spot, as is illustrated in the following account by a female observer (uncorroborated by her male team-mate).

"P1 [18 year-old female] told me that her boyfriend had "just got off with some wee slag on the dancefloor". She seemed drunk, upset and angry. At this point another girl came into the toilets and barged passed us into a newly available cubicle. P1 got pissed off at this and started shouting "if some bitch skips me again I'm gonna boot fuck out them" ... at the far end of the toilet P2, P3 and P4 [18 year-old females] sitting on top of the sinks shouting at P5 in cubicle... P2 was shouting "I know you're in there ya wee bitch. Just wait till you come out" and just kept shouting "bitch" and "slag" at her. I didn't wait to see what happened as there were no staff available in the toilets." (Female Observer, Incident \#30, 'Xanadu')

Incident \#30 was also of interest in that, unusually in this research, it was possible to hear verbal aggression being used. Two similar incidents of female-to-female verbal aggression were witnessed, one, \#22, in the cloakroom of 'Tropicana', the other, \#10, in an elevator of 'Sinatra's'. This latter incident was sparked by the accusation "that's my brother and I'd appreciate it if you didn't point your finger at him" (Female Observer) being made between females (i.e. 'reverse-chivalry'). One incident, \#21, of male-to-male 
verbal aggression was witnessed in the toilet of 'Tropicana', which staff quickly defused. However, the bulk of incidents took place in the dancehalls where the music was invariably too loud for observers to hear anything being said, which seemed to make male conflicts, with their coded body-language easier to spot when trouble was brewing. However, after Incident \#26 (above) the following female body-language was witnessed.

"Later in the night we saw P2 [20 year-old female in blue dress] and P3 [20 yearold female with ponytail] talking animatedly to a male patron boasting about the fight and acting out punching and stamping gestures. Did not see PI [19 year-old female victim] again so I'm assuming she was thrown out, although I don't know why P2 and P3 were allowed to stay.” (Female Observer, Incident \#26, 'Idols')

A content analysis of observers descriptions revealed that both genders were equally likely to punch or kick during conflicts, however as is shown by Table 2, females were more likely to employ hair-pulling, while males were more likely to be recorded as "squaring-up" to an opponent and also to use wrestling holds such as a headlock.

\section{$<$ Table 2>}

\section{Conflict motivators}

Further gender differences were found in comparing what observers viewed as the causes of the aggressive incidents they witnessed. 'Form2' contained a checklist of factors which may have contributed to each aggressive incident. As shown by Table 3, these were recorded as either 'yes' (e.g. yes 'horseplay' was a factor), 'no' or 'maybe' (a 'don't know' option was also provided - responses excluded from Table 3).

\section{$<$ Table 3>}

From Table 3 it can be seen that female combatants were felt by observers to be more often involved in incidents where 'sexual jealousy' was thought to have played a part than was the case with male combatants (chi-square $=34.24 ; p=0.000$ ). In contrast male combatants were more likely to be involved in conflicts where someone 'looking for trouble' was thought to have been a factor (chi-square $=24.63 ; p=0.000$ ). Other significant gender differences concerning the likely causes of aggressive incidents comprised female combatants being more likely to be involved in incidents where observers noted that someone was overly emotional (chi-square $=22.45 ; p=0.000$ ) and where someone appeared to be ('maybe' only) holding a 'grudge' (chi-square $=5.01 ; p=$ 0.025). Male combatants on the other hand were more often involved in incidents related 
to barroom features (e.g. crowding, i.e. resulting in bumping, chi-square $=7.72 ; p=$ 0.021). There was an unclear gender difference in incidents where 'loyalty' may have been a factor (chi-square $=13.06, p=0.001$ ), with more males being coded both 'yes' (no females were) and 'no', while most females were coded 'maybe'.

A second set of questions on 'Form2' asked observers to assess the behaviour of each individual combatant involved in every aggressive incident. This comprised items coded in the same way as on Table 3 (again 'don't know' responses are excluded), plus items relating to levels of aggression and intoxication which were each scored separately on a scale from 0 to 9 . These assessments are shown on Tables 4 and 5 respectively.

$<$ Table 4>

$<$ Table 5>

Tables 4 and 5 revealed less gender differences than anticipated (e.g. in terms of risktaking or rowdy behaviours). Nevertheless, male combatants were more likely to be described as 'unafraid' (chi-square $=9.93 ; p=0.007$ ) and also scored significantly higher in observer assessed intoxication levels $(t=2.31 ; p=0.022)$.

\section{Discussion}

The findings of this research were unexpected, as previous research of this nature has tended to find that aggressive behaviour in bars is a predominantly, or even exclusively, a male activity. This research found female nightclub patrons' aggression to be as severe as that of their male counter-parts and also to be occurring at a relatively similar frequency. Although, as expected, more males than females were witnessed becoming involved in aggressive incidents, it was noteworthy that this picture was skewed by the one club in the sample which had the most incidents, but where an apparently lax door policy had allowed under-age females and over-age but troublesome males to enter. This phenomenon may clarify previous research which has found that the presence of underage females to be linked to aggression in over-age males (Graham et al, 1980).

No examples of male-to-female aggression were witnessed. This finding would appear to be consistent with those of a recent interview study conducted in Buffalo, USA (Collins et al, 2007), which also reports accounts of severe female-to-female barroom aggression, 
with the authors concluding "Our study is unique because the majority (60\%) of the incidents of aggression in bars involved a female initiator and opponent." The Buffalo study found that rowdy behaviour was the best predictor of female-to-female fights, though this "may have contributed to an atmosphere where social activities such as flirting lead to conflict with a romantic partner or over a romantic partner, which was our second most common precipitant of incidents of aggression". This also seems consistent with the findings of this paper, as observers felt that female-to-female conflicts were most often a result of sexual jealousy.

The male aggression witnessed was in-line with much previous research, in that male aggressors were more likely to be looking for a fight, and displaying fearlessness, perhaps utilising the barroom environment to provoke conflict (e.g. by bumping) than was the case with female aggressors. Interestingly male aggressors also appeared to be more intoxicated, a finding which would also appear to be consistent with the Buffalo study (Leonard et al, 2003; Collins et al., 2007) and which would also seem to chime with research indicating that males tend to attribute more of a causal link between substance use and (unpleasant) behaviour (e.g. Crawford, 1984; Rolfe et al, 2006).

Other expected gender differences were not observed. Factors such as risk taking, verbal aggression and chivalry, did not seem to differ by gender, with for example females being prepared to aggressively 'stick up' for males in their company (e.g. Incident \#10). Females were also observed engaging in challenges to fight (e.g. Incident, \#30) and in 'war stories', that is proudly describing their fighting prowess (e.g. Incident, \#26), something which previous research has characterised as 'macho' male behaviour (e.g. Benson \& Archer, 2002; Graham \& Wells, 2003; Tuck, 1989, pp 45-46).

Male conflicts tended to involve a predictable set pre-fight choreography, often beginning with an aggressor 'squaring-up' to an opponent. These two males may then both be assisted by 'seconds' (their male companions), who would either restrain or encourage the combatants towards a stand-up-fight. Because such conflicts tended to involve this set 'code' of pre-fight choreography, they were usually quickly spotted and dealt with by security staff. By contrast it was difficult to spot when a fight was 'brewing' between females as there appeared to be no comparable fixed pre-fight choreography. This is important in the nightclub setting, where the volume of music 
meant that staff would be unable to hear any verbal precursors. Additionally, female fights also tended to involve hair-pulling, which could result in intervening females being pulled in, to produce an entangled melee, creating in a much more difficult situation for staff to resolve.

The situation appeared to be exacerbated by a lack of female security staff, who also appeared to be younger than males, which may reflect a lack of experience. Perhaps as a result of this gender imbalance, and the recognized culture of heightened masculinity amongst male 'bouncers' (e.g. see Hadfield, 2006; Hobbs et al, 2003; Tomsen, 2005), during the course of this research male stewards appeared either to fail to take female conflicts seriously or provide empathy to victims of female-to-female assaults. When male stewards did intervene in a female conflict, they seemed to let female offenders remain on premises whereas male offenders would be ejected. This reluctance among bar staff, to intervene in female conflicts has also been noted elsewhere (e.g. Collins, 2006), perhaps because males are fearful of accusations of sexual assault. The findings of this paper would support the views expressed by 'Stella', a former bouncer now security company owner, interviewed in England by Hobbs and colleagues (2007), that "I used to look at it as women providing a niche market but it's not any more, women have to be employed in these venues. You can't have men searching women or dragging women out of the toilets with their knickers round their ankles."

In the absence of longitudinal evidence, these findings beg the question of whether alcohol-related violence between females is a new or rising phenomenon. There are three possible explanations as to why there should be near gender equality in barroom disorder in the UK at present. The first of these may be described as the 'ladette hypothesis', as proposed by the media. That is young women are drinking and fighting more than was the case in previous generations. This could be explained by feminised barrooms retaining their 'hyper-masculine' characteristics, thus creating the 'macho' female (see also Graham \& Homel, 2008). Alternatively the gentrification of the barroom environment to appeal to more female drinkers may actually reduce male aggression. This 'feminisation hypothesis' would appear to have some support from research which has found that making barroom surroundings more comfortable ('upscale') reduces violence risk (e.g. Graham et al, 1980; Homel \& Clark, 1994). It is certainly the case that more serious alcohol-related violence, which tends to occur away from the controlled 
environment of the barroom, such as knife crime, has remained very much a male pursuit. Finally it may simply be that as more women are drinking in barrooms femaleto-female conflicts are becoming more visible, rather than it being the case that females are becoming more violent, or males less so. Support for this 'normalisation hypothesis' includes the rising number of female barroom drinkers and also some evidence that youth cultures are becoming less gender specific. For example, in Glasgow, Sweeting and West (2003) found that over the 1990s, successive cohorts of 15 year-old females had moved away from a 'bedroom culture' to a 'going-out' culture, while males of the same age had moved in the opposite direction.

It was noteworthy that during both the research for the present paper and the previous Glasgow 'pub study' (Forsyth et al, 2005) observers referred to hostile female barroom environments as being 'wedding-like' (see also Eldridge \& Roberts, 2008). This suggests a lay familiarity with female-to-female aggression in other (non-barroom, but 'wet') settings. The contention that alcohol-related female aggression is nothing new can be supported in the literature, documenting such behaviour in both the recent and more distant past (e.g. Day et al, 2003, by interview and Warner et al, 2005, from court records, respectively). This would also appear to be the case in Glasgow nightclubs as the following excerpt from the Scotsman newspaper in 1916 illustrates: “...the complainer who stated that she resided in [Glasgow], and was the wife of a soldier now on active service said she was in a dancing hall... Accused found fault with her singing during the music. Later in a side room, she struck her in the face and there was a fight."

\section{Conclusions}

That this research had a relatively high proportion of female-to-female conflicts is perhaps unsurprising, given that the majority of drinkers were female. However, as only one fifth of security staff were female, a need for more gender sensitive barroom security has been identified. In the absence of longitudinal data it is impossible to know whether alcohol-related female-to-female violence of the type described in this paper is rising or has merely been overlooked. 


\section{Statement of competing interest}

This paper is based on research funded by the Alcohol Education Research Council (AERC).

\section{Acknowledgement}

The authors would like to thank Andy Boyd, Katie O'Neil, Steve Parkin and Tom Woods for their observational fieldwork, as well as Professor Kathryn Graham of the Centre for Addiction and Mental Health, University of Western Ontario, London, Canada for her kind permission to use her research instruments.

\section{References}

BBC2 Television (2004). Booze Business. The Money Programme, October $27^{\text {th }}$ and November $3^{\text {rd }}$.

BBC3 Television (2006) Binge Drinker. Mischief, January $12^{\text {th }}$.

Benson, D. \& Archer, J. (2002) An ethnographic study of sources of conflict between young men in the context of the night out. Psychology, Evolution and Gender, 4:3-31.

Borland, S. (2008) Fines for loutish 'ladettes' treble since 24-hour drinking was introduced. Daily Mail, December $27^{\text {th }}$.

Buddie, A. M. \& Parks, K. A. (2003) The role of the bar context and social behaviors on women's risk for aggression. Journal of Interpersonal Violence, 18:1378-1393.

Burns, T. (1980) Getting rowdy with the boys. Journal of Drug Issues, 10:273-287.

Campbell, H., Law, R. \& Honeyfield, J. (1999) What It Means to be a Man: Hegemonic masculinity and the reinvention of beer. In Law, R., Campbell, H. \& Dolan, J. (Eds.) Masculinities in Aotearoa / New Zealand, pp. 166-186. Dunmore Press: Palmerston North.

Chatterton, P. \& Hollands, R. with Byrnes, C. B. \& Read, C. (2001) Changing Our Toon: Youth nightlife and urban change in Newcastle. Newcastle: University of Newcastle.

Chatterton, P. \& Hollands, R. (2003) Urban Nightscapes Youth Cultures, Pleasure Spaces and Corporate Power. London: Routledge.

Collins, R. L., Quigley, B. M., \& Leonard, K. E. (2007) Women's physical aggression in bars: An event-based examination of precipitants and predictors of severity. Aggressive Behavior, 33:304-313.

Crawford, A. (1984) Alcohol and Expectancy I: Perceived sex differences in the effects of drinking, \& II: Perceived sex differences in the role of alcohol as a source of aggression. Alcohol and Alcoholism, 19:63-69 \& 71-75. 
Day, K., Gough, B. \& McFadden, M. (2003) Women who drink and fight: A discourse analysis of working-class women's talk. Feminism and Psychology, 13:141-158.

De Crespigny, C. (2001) Young Women, Pubs and Safety. In: Williams, P. (Ed.) Alcohol, Young Persons and Violence, 31-46. Canberra: Australian Institute of Criminology.

http://www.aic.gov.au/publications/rpp/35/RPP35.pdf

De Visser, R. O. \& Smith, J. A (2007) Alcohol consumption and masculine identity among young men. Psychology and Health, 22:595-614.

Dooldeniya, M. D., Khafagy, R., Mashaly, H., Browning, A. J., Sundaram, S. K. \& Biyani, C. S. (2007) Lower abdominal pain in women after binge drinking. British Medical Journal, 335:992-993.

Dow, J. \& McIntosh, R. (2004) Brewers bid to make pint drinking pretty. The Scotsman, June $5^{\text {th }}$.

Eldridge, A. \& Roberts, M. (2008) Hen Parties: Bonding or brawling. Drugs: Education, Prevention and Policy, 15:323-328.

Forsyth, A. J. M., Cloonan, M. \& Barr, J. (2005) Factors Associated with Alcoholrelated Problems within Licensed Premises. Glasgow: Greater Glasgow NHS Board. http://www.nhsggc.org.uk/content/assetList.asp?aType $=15 \&$ aSType $=184 \& p a g e=s 775 \_2$

Graham, K. (1999) Safer Bars: Assessing and Reducing Risks of Violence. Toronto: Centre for Addiction and Mental Health.

Graham, K. (2000) Safer Bars: Training Manual for Observers on the Safer Bars Study. Toronto: Centre for Addiction and Mental Health. http://publish.uwo.ca/ kgraham/safer_bars.html

Graham, K. \& Homel, R. (2008) Raising the Bar: Understanding and preventing violence and aggression in bars, pubs and clubs. Devon: Willan.

Graham, K., Tremblay, P. F., Wells, S., Pernanen, K., Purcell, K. \& Jelley, J. (2006) Harm, Intent and the nature of Aggressive Behavior of Males and Females: Measuring naturally occurring aggression in barroom settings. Assessment, 13:280-296.

Graham, K. \& Wells, S. (2001) The two worlds of aggression for men and women. Sex Roles: A Journal of Research, 45:595-622.

Graham, K. \& Wells, S. (2003) 'Somebody's gonna get their head kicked in tonight': Aggression among young males in bars - a question of values. British Journal of Criminology, 43:546-566.

Gray, L. (2006) Alcohol kills record number of women. Scotsman, July $29^{\text {th }}$.

Hadfield, P. (2006) Bar Wars: Contesting the night in contemporary British cities. Oxford: Oxford University Press. 
Harrell, E. \& Howie, M. (2006) Violent crime by women up 50 per cent in past 4 years. The Scotsman, September $1^{\text {st }}$.

Hinsliff, G. (2004). Bingeing Women Fuel Crime: Blunkett warns of soaring violence as alcohol culture spirals out of control. The Observer, July $18^{\text {th }}$.

Hobbs, D., Hadfield, P., Lister, S. \& Winlow, S. (2003) Bouncers: Violence and Governance in the Night-time Economy. Oxford, Oxford University Press.

Hobbs, D, O'Brien, K. \& Westmarland, L. (2007) Connecting the Gendered Door: Women, Violence and Doorwork, British Journal of Sociology, 58:21-38.

Homel, R., \& Clark, J. (1994) The prediction and prevention of violence in pubs and clubs. Crime Prevention Studies, 3:1-46.

Lang, A. R., Gaeskner, D. J., Adesso, V. J. \& Marlatt, G. A. (1975) Effects of alcohol on aggression in male social drinkers. Journal of Abnormal Psychology, 84:508-518.

Leonard K. E., Collins R. L. \& Quigley, B. M. (2003) Alcohol consumption and the occurrence and severity of aggression: An event-based analysis of male to male barroom violence. Aggressive Behavior, 29:346-365.

McRobbie, A. (2004). Free to Vomit in the Gutter: The forces that are shaping young women's attitudes to sex and drink mark a corrosion of feminist values. The Guardian, June $7^{\text {th }}$.

Moore, D. (1990) Drinking, the construction of ethnic identity and social process in a Western Australia youth subculture. British Journal of Addiction, 85:1265-1279.

Moynihan, C. (1998). Theories in Health Care and Research: Theories of masculinity. British Medical Journal, 317:1072-1075.

Murdoch, D. \& Pihl, R. (1988) The influence of beverage type on aggression in males in the natural setting. Aggressive Behavior, 14:3325-3335.

Parks, K. A. (1999) Women's Bar-related Victimization: Refining and testing a conceptual model. Aggressive Behaviour, 25:349-364.

Parks, K. A. (2000) Event based analysis of aggression women experience in bars. Psychology of Addiction Behaviors, 14:102-110.

Plant M. L., Miller, P. \& Plant, M. A. (2005) The relationship between alcohol consumption and problem behaviours: Gender differences among British adults. Journal of Substance Use, 10:22-30.

Rolfe, A., Dalton, S., Krishnan, M., Orford, J., Mehdikhani, M., Cawley, J. \& FerrinsBrown, M. (2006). Alcohol, Gender, Aggression and Violence: Findings from the Birmingham untreated heavy drinkers project. Journal of Substance Use, 11: 5, 343-358. 
Slack, J. (2008) Menace of the Violent Girls: Binge-drinking culture fuels surge in attacks by women. Daily Mail, July $31^{\text {st }}$.

Smith, E. \& Taher, A. Ladettes fuel rise in drink-drive woman. The Times, January $8^{\text {th }}$.

Strate, L. (1992) Beer Commercials: A manual on masculinity. In Craig, S. (Ed.) Men, Masculinity, and the Media: Research on men and masculinities, pp. 78-92, Newbury Park: Sage.

Sweeting, H. \& West, P. (2003) Young People's Leisure and Risk-Taking Behaviours: Changes in Gender Patterning in the West of Scotland during the 1990s. Journal of Youth Studies, 6:391-412.

Taylor-Whiffen, P. (2006) Why Women Want to Join the Club: The boom in the nighttime economy has prompted a sharp rise in the number of female bouncers. The Independent, October $3^{\text {rd }}$.

Testa, M. \& Parks, K. A. (1996). The role of women's alcohol consumption in sexual victimization. Aggression and Violent Behaviour, 1:217-234.

Tomsen, S. A. (1997). A Top Night Out: Social protest, masculinity and the culture of drinking violence. British Journal of Criminology, 37:90-102.

Tomsen, S. A. (2005) Boozers and Bouncers: Masculine conflict, disengagement and the contemporary governance of drinking-related violence and disorder. The Australian and New Zealand Journal of Criminology, 38:283-297.

Tuck, M. (1989) Drinking and Disorder: A Study of Non-Metropolitan Violence. Home Office Research Study, No. 108. London: HMSO.

Warner, J., Graham, K., Adlaf, E. (2005). Women behaving badly: Gender and aggression in a military town, 1653-1781. Sex Roles, 52:289-298. 
Table 1: Nightclubs characteristics, recorded and observed violence / aggression

\begin{tabular}{|c|c|c|c|c|c|c|}
\hline \multirow[t]{2}{*}{ Venue } & \multirow{2}{*}{$\begin{array}{c}\text { Recorded } \\
\text { Crimes } \\
2005\end{array}$} & \multirow{2}{*}{$\begin{array}{l}\text { Est. } n \text { of } \\
\text { patrons }\end{array}$} & \multirow{2}{*}{$\begin{array}{l}\text { Est. \% } \\
\text { Female } \\
\text { patrons }\end{array}$} & \multirow{2}{*}{$\begin{array}{l}\text { Incidents } \\
\text { Observed }\end{array}$} & \multicolumn{2}{|c|}{ Genders in incidents $(n)$} \\
\hline & & & & & Patrons & Staff \\
\hline Xanadu & 102 & 241 & 58.5 & 8 & $18 \mathrm{M}: 25 \mathrm{~F}$ & $25 \mathrm{M}: 0 \mathrm{~F}$ \\
\hline Armageddon & 76 & 246 & 50.6 & 11 & $37 \mathrm{M}: 4 \mathrm{~F}$ & $41 \mathrm{M}: 2 \mathrm{~F}$ \\
\hline Tropicana & 72 & 252 & 60.6 & 4 & $7 \mathrm{M}: 2 \mathrm{~F}$ & $9 \mathrm{M}: 3 \mathrm{~F}$ \\
\hline Chocolate & 48 & 197 & 57.6 & 2 & $10 \mathrm{M}: 0 \mathrm{~F}$ & $9 \mathrm{M}: \mathrm{OF}$ \\
\hline Idols & 42 & 258 & 60.6 & 5 & $22 \mathrm{M}: 20 \mathrm{~F}$ & $26 \mathrm{M}: 6 \mathrm{~F}$ \\
\hline Rapture & 35 & 251 & 52.5 & 0 & - & - \\
\hline Sinatra's & 25 & 248 & 58.8 & 4 & $14 \mathrm{M}: 12 \mathrm{~F}$ & $12 \mathrm{M}: 0 \mathrm{~F}$ \\
\hline Saturn & 0 & 154 & 45.0 & 0 & - & - \\
\hline
\end{tabular}


Table 2: Observed conflict tactics by combatants' gender

\begin{tabular}{|l|c|c|c|c|}
\hline Conflict tactics & Females & Males & Any & $\begin{array}{l}\text { P value } \\
\text { (chi -square) }\end{array}$ \\
\hline "Square-up" & $0(-)$ & $10(9.3 \%)$ & $10(5.8 \%)$ & 0.009 \\
\hline Shove / push / jostle & $8(12.7 \%)$ & $22(20.4 \%)$ & $30(17.5 \%)$ & Non-significant \\
\hline Wrestle-hold / head-lock & $2(3.2 \%)$ & $20(18.5 \%)$ & $22(12.9 \%)$ & 0.002 \\
\hline Punch / slap & $19(30.2 \%)$ & $37(34.3 \%)$ & $56(32.7 \%)$ & Non-significant \\
\hline Kick / stamp & $5(7.9 \%)$ & $8(7.4 \%)$ & $13(7.6 \%)$ & Non-significant \\
\hline Head-butt & $0(-)$ & $2(1.9 \%)$ & $2(1.2 \%)$ & Non-significant \\
\hline Hair-pull & $25(39.7 \%)$ & $0(-)$ & $25(14.6 \%)$ & 0.000 \\
\hline Use object & $2(3.2 \%)$ & $1(0.9 \%)$ & $3(1.8 \%)$ & Non-significant \\
\hline Throw object & $0(-)$ & $5(4.6)$ & $5(2.9 \%)$ & Non-significant \\
\hline Floor (i.e. victim) & $4(6.3 \%)$ & $10(9.3 \%)$ & $14(8.2 \%)$ & Non-significant \\
\hline & & & & \\
ALL & 63 & 108 & 171 & - \\
\hline
\end{tabular}


Table 3: Observer assessed causal factors in aggressive incidents

\begin{tabular}{|c|c|c|c|c|c|}
\hline $\begin{array}{l}\text { Factor in } \\
\text { incident }\end{array}$ & Gender & 'No' & 'Maybe' & 'Yes' & $\begin{array}{l}P \text { value } \\
\text { (chi-square) }\end{array}$ \\
\hline \multirow{2}{*}{$\begin{array}{l}\text { Sexual } \\
\text { jealousy }\end{array}$} & Females & $7(12.7 \%)$ & $33(57.9 \%)$ & $17(29.8 \%)$ & \multirow[t]{2}{*}{0.000} \\
\hline & Males & $43(50.6 \%)$ & $40(47.1 \%)$ & $2(2.4 \%)$ & \\
\hline \multirow{2}{*}{$\begin{array}{l}\text { Looking } \\
\text { for a fight }\end{array}$} & Females & $26(66.7 \%)$ & $13(33.3 \%)$ & $0(-)$ & \multirow[t]{2}{*}{0.000} \\
\hline & Males & $21(24.4 \%)$ & $42(48.8 \%)$ & $23(26.7 \%)$ & \\
\hline \multirow{2}{*}{$\begin{array}{l}\text { Fight for } \\
\text { fun }\end{array}$} & Females & $32(72.7 \%)$ & $8(18.2 \%)$ & $4(9.1 \%)$ & \multirow{2}{*}{$\begin{array}{c}\text { Non- } \\
\text { significant }\end{array}$} \\
\hline & Males & $54(64.3 \%)$ & $14(16.7 \%)$ & $16(19.0 \%)$ & \\
\hline \multirow[t]{2}{*}{ Loyalty } & Females & $16(28.6 \%)$ & $40(71.4 \%)$ & $0(-)$ & \multirow[t]{2}{*}{0.001} \\
\hline & Males & $31(34.8 \%)$ & $43(48.3 \%)$ & $15(16.9 \%)$ & \\
\hline \multirow{2}{*}{$\begin{array}{l}\text { Defending } \\
\text { action }\end{array}$} & Females & $22(40.7 \%)$ & $27(50.0 \%)$ & $5(9.3 \%)$ & \multirow{2}{*}{$\begin{array}{c}\text { Non- } \\
\text { significant }\end{array}$} \\
\hline & Males & $38(43.7 \%)$ & $31(35.6 \%)$ & $18(20.7 \%)$ & \\
\hline \multirow{2}{*}{$\begin{array}{l}\text { Taking } \\
\text { offence }\end{array}$} & Females & $15(27.3 \%)$ & $35(63.6 \%)$ & $5(9.1 \%)$ & \multirow{2}{*}{$\begin{array}{c}\text { Non- } \\
\text { significant }\end{array}$} \\
\hline & Males & $30(34.5 \%)$ & $41(47.1 \%)$ & $16(18.4 \%)$ & \\
\hline \multirow[t]{2}{*}{ Insults } & Females & $17(30.9 \%)$ & $27(49.1 \%)$ & $11(20.0 \%)$ & \multirow{2}{*}{$\begin{array}{c}\text { Non- } \\
\text { significant }\end{array}$} \\
\hline & Males & $35(43.8 \% 0$ & $35(43.8 \%)$ & $10(12.5 \%)$ & \\
\hline \multirow{2}{*}{$\begin{array}{l}\text { Overly } \\
\text { Emotional }\end{array}$} & Females & $5(8.2 \%)$ & $36(59.0 \%)$ & $20(32.8 \%)$ & \multirow[t]{2}{*}{0.000} \\
\hline & Males & $36(43.9 \%)$ & $33(40.2 \%)$ & $13(15.9 \%)$ & \\
\hline \multirow{2}{*}{$\begin{array}{l}\text { Heated } \\
\text { discussion }\end{array}$} & Females & $11(18.6 \%)$ & $28(47.5 \%)$ & $20(33.9 \%)$ & \multirow{2}{*}{$\begin{array}{c}\text { Non- } \\
\text { significant }\end{array}$} \\
\hline & Males & $27(30.0 \%)$ & $34(37.8 \%)$ & $29(32.2 \%)$ & \\
\hline \multirow[t]{2}{*}{ Grudge } & Females & $29(58.0 \%)$ & $21(42.0 \%)$ & $0(-)$ & \multirow[t]{2}{*}{0.025} \\
\hline & Males & $62(76.5 \%)$ & $19(23.5 \%)$ & $0(-)$ & \\
\hline \multirow[t]{2}{*}{ Horseplay } & Females & $51(92.7 \%)$ & $2(3.6 \%)$ & $2(3.6 \%)$ & \multirow{2}{*}{$\begin{array}{c}\text { Non- } \\
\text { significant }\end{array}$} \\
\hline & Males & $85(90.4 \%)$ & $9(9.6 \%)$ & $0(-)$ & \\
\hline \multirow{2}{*}{$\begin{array}{l}\text { Aspect of } \\
\text { Barroom }\end{array}$} & Females & $53(96.4 \%)$ & $1(1.8 \%)$ & $1(1.8 \%)$ & \multirow[t]{2}{*}{0.021} \\
\hline & Males & $72(80.0 \%)$ & $11(12.2 \%)$ & $7(7.8 \%)$ & \\
\hline
\end{tabular}


Table 4: Observer assessed behaviours of combatants in aggressive incidents

\begin{tabular}{|c|c|c|c|c|c|}
\hline $\begin{array}{l}\text { Behaviour } \\
\text { of patron }\end{array}$ & Gender & 'No' & 'Maybe' & 'Yes' & $\begin{array}{l}P \text { value } \\
\text { (chi-square) }\end{array}$ \\
\hline \multirow{2}{*}{$\begin{array}{l}\text { Focused on } \\
\text { the situation }\end{array}$} & Females & $20(39.2 \%)$ & $9(17.6 \%)$ & $22(43.1 \%)$ & \multirow{2}{*}{$\begin{array}{c}\text { Non- } \\
\text { significant }\end{array}$} \\
\hline & Males & $24(27.6 \%)$ & $21(24.1 \%)$ & $42(48.3 \%)$ & \\
\hline \multirow[t]{2}{*}{ Unafraid } & Females & $20(35.5 \%)$ & $17(29.3 \%)$ & $21(36.2 \%)$ & \multirow[t]{2}{*}{0.007} \\
\hline & Males & $24(31.0 \%)$ & $12(15.5 \%)$ & $56(60.9 \%)$ & \\
\hline \multirow{2}{*}{$\begin{array}{l}\text { Over- } \\
\text { reacting }\end{array}$} & Females & $18(31.0 \%)$ & $9(15.5 \%)$ & $31(53.4 \%)$ & \multirow{2}{*}{$\begin{array}{c}\text { Non- } \\
\text { significant }\end{array}$} \\
\hline & Males & $16(20.0 \%)$ & $19(23.8 \%)$ & $45(56.3 \%)$ & \\
\hline \multirow{2}{*}{$\begin{array}{l}\text { Hyper } \\
\text { stimulated }\end{array}$} & Females & $27(48.2 \%)$ & $17(30.4 \%)$ & $12(21.4 \%)$ & \multirow{2}{*}{$\begin{array}{c}\text { Non- } \\
\text { significant }\end{array}$} \\
\hline & Males & $30(31.9 \%)$ & $28(29.8 \%)$ & $36(38.3 \%)$ & \\
\hline \multirow{2}{*}{$\begin{array}{l}\text { Power } \\
\text { tripping }\end{array}$} & Females & $44(86.3 \%)$ & $4(7.8 \%)$ & $3(5.9 \%)$ & \multirow{2}{*}{$\begin{array}{c}\text { Non- } \\
\text { significant }\end{array}$} \\
\hline & Males & $62(74.7 \%)$ & $8(9.6 \%)$ & $13(15.7 \%)$ & \\
\hline \multirow{2}{*}{$\begin{array}{l}\text { Unaware of } \\
\text { perspectives }\end{array}$} & Females & $21(38.9 \%)$ & $21(36.9 \%)$ & $12(22.2 \%)$ & \multirow{2}{*}{$\begin{array}{c}\text { Non- } \\
\text { significant }\end{array}$} \\
\hline & Males & $25(27.5 \%)$ & $50(54.9 \%)$ & $16(17.6 \%)$ & \\
\hline \multirow[t]{2}{*}{ Impulsive } & Females & $16(32.0 \%)$ & $12(24.0 \%)$ & $22(44.0 \%)$ & \multirow{2}{*}{$\begin{array}{c}\text { Non- } \\
\text { significant }\end{array}$} \\
\hline & Males & $25(29.1 \%)$ & $19(22.1 \%)$ & $42(48.8 \%)$ & \\
\hline \multirow[t]{2}{*}{ Carried away } & Females & $18(31.0 \%)$ & $16(27.6 \%)$ & $24(41.4 \%)$ & \multirow{2}{*}{$\begin{array}{c}\text { Non- } \\
\text { significant }\end{array}$} \\
\hline & Males & $16(17.0 \%)$ & $22(23.4 \%)$ & $56(59.6 \%)$ & \\
\hline \multirow[t]{2}{*}{ Risk taking } & Females & $18(31.6 \%)$ & $12(21.1 \%)$ & $27(47.4 \%)$ & \multirow{2}{*}{$\begin{array}{c}\text { Non- } \\
\text { significant }\end{array}$} \\
\hline & Males & $22(25.3 \%)$ & $21(24.1 \%)$ & $44(50.6 \%)$ & \\
\hline \multirow{2}{*}{$\begin{array}{l}\text { Unable to } \\
\text { think clearly }\end{array}$} & Females & $17(29.8 \%)$ & $19(33.3 \%)$ & $21(36.8 \%)$ & \multirow{2}{*}{$\begin{array}{c}\text { Non- } \\
\text { significant }\end{array}$} \\
\hline & Males & $29(34.1 \%)$ & $35(41.2 \%)$ & $21(24.7 \%)$ & \\
\hline \multirow{2}{*}{$\begin{array}{l}\text { Failing to } \\
\text { comprehend }\end{array}$} & Females & $19(33.3 \%)$ & $26(45.6 \%)$ & $12(21.1 \%)$ & \multirow{2}{*}{$\begin{array}{c}\text { Non- } \\
\text { significant }\end{array}$} \\
\hline & Males & $21(25.6 \%)$ & $29(35.4 \%)$ & $32(39.0 \%)$ & \\
\hline \multirow{2}{*}{$\begin{array}{l}\text { Stumbling or } \\
\text { slurring }\end{array}$} & Females & $16(34.8 \%)$ & $8(17.4 \%)$ & $22(47.8 \%)$ & \multirow{2}{*}{$\begin{array}{c}\text { Non- } \\
\text { significant }\end{array}$} \\
\hline & Males & $13(24.1 \%)$ & $11(20.4 \%)$ & $30(55.6 \%)$ & \\
\hline
\end{tabular}


Table 5: Observer assessed combatants' levels of aggression and intoxication

\begin{tabular}{|c|c|c|c|c|c|}
\hline & gender & $N$ & $\begin{array}{c}\text { Mean score } \\
(0 \text { to } 9) \\
\end{array}$ & $\begin{array}{l}\text { Standard } \\
\text { Deviation }\end{array}$ & $\begin{array}{l}P \text { value } \\
(t \text {-test })\end{array}$ \\
\hline \multirow{2}{*}{$\begin{array}{l}\text { Overall } \\
\text { Threat level }\end{array}$} & Females & 46 & 3.8 & 1.82 & \multirow{2}{*}{$\begin{array}{c}\text { Non- } \\
\text { significant }\end{array}$} \\
\hline & Males & 74 & 4.2 & 1.70 & \\
\hline \multirow{2}{*}{$\begin{array}{l}\text { Verbal } \\
\text { aggression }\end{array}$} & Females & 49 & 5.0 & 1.58 & \multirow{2}{*}{$\begin{array}{c}\text { Non- } \\
\text { significant }\end{array}$} \\
\hline & Males & 77 & 4.9 & 1.67 & \\
\hline \multirow{2}{*}{$\begin{array}{l}\text { Physical } \\
\text { aggression }\end{array}$} & Females & 43 & 4.2 & 1.74 & \multirow{2}{*}{$\begin{array}{c}\text { Non- } \\
\text { significant }\end{array}$} \\
\hline & Males & 79 & 4.3 & 1.57 & \\
\hline \multirow{2}{*}{$\begin{array}{l}\text { Pain felt (if } \\
\text { relevant) }\end{array}$} & Females & 30 & 3.9 & 1.83 & \multirow{2}{*}{$\begin{array}{c}\text { Non- } \\
\text { significant }\end{array}$} \\
\hline & Males & 42 & 3.2 & 2.21 & \\
\hline \multirow{2}{*}{$\begin{array}{l}\text { Intoxication } \\
\text { level }\end{array}$} & Females & 60 & 5.9 & 1.54 & \multirow[t]{2}{*}{0.011} \\
\hline & Males & 90 & 6.5 & 1.45 & \\
\hline
\end{tabular}

